\title{
AMINO ACID CONTENT AND BIOMASS PRODUCTIVITY OF SELECTED WEED SPECIES AS AN INDICATOR OF THEIR RESPONSE TO HERBICIDE STRESS
}

\author{
Renata Kieloch, Jerzy Sadowski, Krzysztof Domaradzki \\ Institute of Soil Science and Plant Cultivation, State Research Institute \\ Orzechowa 61, 50-540 Wrocław, Poland \\ e-mail: r.kieloch@iung.wroclaw.pl
}

Received: 15.03.2013

\begin{abstract}
Biomass reduction and amino acid content in plants of Papaver rhoeas L. and Stellaria media L. were investigated to evaluate response of these species to herbicide stress under various temperature $\left(25 / 16\right.$ and $\left.8 / 2{ }^{\circ} \mathrm{C}\right)$ and relative humidity (50 and $75 \%$ ) regimes. Weeds were treated with tribenuron methyl $\left(15 \mathrm{~g} \times \mathrm{ha}^{-1}\right)$, a mixture of 2.4-D with florasulam (180+ $\left.3.75 \mathrm{~g} \times \mathrm{ha}^{-1}\right)$, and a mixture of 2.4-D with dicamba (1252.5 $\left.+97.5 \mathrm{~g} \times \mathrm{ha}^{-1}\right)$. The fresh weight of weeds and the content of free branched-chain amino acids (valine, leucine and isoleucine) in plant tissue were recorded. Tribenuron methyl was the herbicide that most limited biomass productivity, regardless of weed species and climate conditions. S. media was more sensitive to herbicides than $P$. rhoeas. Weed response to herbicides was dependent on temperature, but not on relative humidity. Tribenuron methyl applied to both weed species under various temperature regimes caused significant amino acid deficiency. The reduction in amino acid content in plants of $P$. rhoeas was greater at warm temperature compared to the cold regime due to stronger reaction to tribenuron methyl applied under these conditions. In most of cases, the mixture of 2.4-D + dicamba induced overproduction of amino acids.
\end{abstract}

Key words: Papaver rhoeas L., Stellaria media L., fresh weight reduction, tribenuron methyl, 2.4-D + florasulam, 2.4-D + dicamba, valine, leucine, isoleucine

\section{INTRODUCTION}

Herbicides disturb the physiological and biochemical pathways and this is ultimately reflected in weed biomass reduction. The most popular and numerous is a group of sulfonylurea herbicides which is relatively new; these herbicides inhibit the biosynthesis of branched-chain amino acids by blocking the activity of the acetolactate enzyme [1]. Other herbicides widely used by Polish farmers are auxinic herbicides such as 2.4-D or dicamba. Their mechanism of action is similar to natural phytohormones [2].

The response of weeds to a particular herbicide is a species-specific inborn property, but it may be strongly modified by growth conditions. Weather conditions affect both herbicide spray solution activity on treated surfaces and inside plant tissue as well as the morphological characters of weeds related to herbicide uptake, i.e. cuticle thickness, leaf contact angle or leaf area $[3,4]$. It is well known that environmental conditions that are conducive to plant growth also favour herbicide activity by improving the ability of weeds to perceive and translocate spray solution [5].

From the practical point of view, biomass reduction is the most important indicator of weed response to a herbicide, but there is little information about the changes in metabolic pathways, especially when a slow-acting herbicide is used. The application of sulfonylurea herbicides leads to branched-chain amino acid deficiency in susceptible weeds as a result of blocking the ALS enzyme and consequently to the inhibition of the biosynthesis of these amino acids [6]. Apart from this group, the chemical industry offers a large number of herbicides with different mode of action, changing the content of amino acids in plants by disturbing other metabolic pathways. Amino acid content in plant tissue may be affected not only by herbicides designed to inhibit amino acid biosynthesis, but also by other ones that influence nitrogen metabolism indirectly $[7,8,9,10,11,12]$.

The amino acid pool is subjected to dynamic changes. For example, S h i m et al. [13] reported an increase in free amino acid content with an increasing dose of azimsulfuron and explained it by the reactivation 
of metabolic pathways leading to the introduction of compounds that had been received from amino acid degradation. B e s t m a n et al. [14] also proved an increase in free amino acid content after chlorsulfuron application as a result of secondary transformation of amino acids and proteins in plants. Amino acid content may also be affected by environmental stress, i.e. drought, heating stress, pollution or the interaction between environmental and herbicidal stress. According to $\mathrm{H} \mathrm{j}$ or $\mathrm{th}$ et al. [15], the increase in amino acid content in plants of Apera spica-venti L. sprayed with prosulfocarb may be due to joint action of herbicide and environmental conditions that induce particular biochemical processes leading to an abundance of these compounds.

The objective of this study was to evaluate the effect of tribenuron methyl, the mixture of 2.4-D with florasulam and the mixture of 2.4-D with dicamba on biomass productivity and the content of free branched-chain amino acids in Papaver rhoeas and Stellaria media plants.

\section{MATERIALS AND METHODS}

\section{Plant material}

Seeds of Papaver rhoeas L. (Field poppy) and Stellaria media L. (Common chickweed) were collected from mature weeds growing on herbicide-free plots of arable land located in the Lower Silesia region (Poland). Seeds were planted in $10 \mathrm{~cm}$-diameter plastic pots filled with a mixture of sphagnum peat and sand $(1: 2 \mathrm{v} / \mathrm{v})$. Ten seeds were evenly distributed over the area of each pot, at a depth of $0.5 \mathrm{~cm}$. Immediately after sowing the pots were placed in controlled climate chambers under different temperature and relative humidity conditions. In the temperature study, two levels were involved: $25 / 16^{\circ} \mathrm{C}$ and $8 / 2{ }^{\circ} \mathrm{C}$, under a photoperiod of $450-500 \mu \mathrm{mol} \times \mathrm{m}^{-2} \mathrm{~s}^{-1}$ light intensity and $14 \mathrm{~h}$ day and $10 \mathrm{~h}$ night. In the humidity study, two different relative humidity regimes were involved: 50 and $75 \%$, with constant temperature of $20 / 10{ }^{\circ} \mathrm{C}$, light intensity 450-500 $\mu \mathrm{mol} \times \mathrm{m}^{-2} \mathrm{~s}^{-1}$ and a $14 \mathrm{~h}$ day/10 $\mathrm{h}$ night cycle.

One day before herbicide treatment, weeds were thinned to four uniform and healthy plants per pot. At the time of spraying, weeds were at the 2-4 leaf growth stage. The following herbicides were used: 1 . tribenuron methyl $\left(15 \mathrm{~g} \times \mathrm{ha}^{-1}\right)$ was applied in a mixture with surfactant ( $90 \%$ of isodecyl alcohol) at a concentration $0.05 \%$; 2. the mixture of 2.4-D with florasulam (180 g $\left.\times \mathrm{ha}^{-1}+3.75 \mathrm{~g} \times \mathrm{ha}^{-1}\right)$; 3. the mixture of 2.4-D with dicamba $\left(1252.5 \mathrm{~g} \times \mathrm{ha}^{-1}+97.5 \mathrm{~g} \times \mathrm{ha}^{-1}\right)$. The experiment also comprised untreated plants (no herbicide treatment). The herbicides were applied using a laboratory sprayer fitted with a beam equipped with TeeJet XR 11003-VS flat fan nozzles. The nozzles were operated at a pressure of $200 \mathrm{kPa}$ and a speed of $2.5 \mathrm{~km}$ $\times \mathrm{h}^{-1}$, producing a spray volume of $250 \mathrm{l} \times \mathrm{ha}^{-1}$.

Three weeks after treatment, the green parts of weeds were cut above ground and their fresh weight was determined.

\section{Amino acid analysis}

Plant material for amino acid analysis was sampled 7 days after treatment, by cutting whole aboveground parts of plants. From each treatment, $2 \mathrm{~g}$ of biomass was taken for amino acid content analysis. Plant samples were minced and extracted using $15 \mathrm{ml}$ distilled water. The extract was centrifuged at 4000 RPM to separate the sample matrix and derivatized to obtain volatile derivatives of amino acids. From each sample, $12 \mathrm{ml}$ of the solution was taken for evaporation at $50{ }^{\circ} \mathrm{C}$, using a rotary evaporator. The dry remainder (residues) in the solution was dissolved in $2 \mathrm{ml}$ distilled water and centrifuged at 4000 RPM for 10 minutes. In the next step, derivatives were purified from contaminants. To purify the samples and to obtain amino acid derivatives, an EZ Faast (GC/MS) Amino Acid Analysis kit (Phenomenex) was used; it contains all necessary reagents and materials for sample rectification and derivative isolation. The EZ:faast amino acid analysis procedure consists of a few steps. The first one is solid phase extraction, then derivatization, and the last one is liquid/liquid extraction. The solid phase extraction is performed using a sorbent packed tip that binds amino acids, while other interfering compounds are not bound and flow through. The bound amino acids are derivatized with a reagent at room temperature in aqueous solution. The derivatized amino acids are then found in the organic layer and are additionally separated from interfering compounds. Before analysis, the organic layer is removed, evaporated and re-suspended. Finally, the derivatives can be analyzed using gas chromatography with mass spectrometer detection (GC-MS). The system was adjusted as follows: gas chromatograph VARIAN CP-3800, mass detector VARIAN SATURN 2200, chromatographic column VARIAN VF- $5 \mathrm{~ms} 30 \mathrm{~m}$ length and $0.25 \mathrm{~mm}$ diameter, with temperature $120-130^{\circ} \mathrm{C}$. Carrier gas was nitrogen, at a flowing rate of $1.5 \mathrm{ml}$ per 1 minute.

\section{Data analysis}

The data obtained from the fresh weight and amino acid analysis were subjected to Tukey's HSD test to determine the significance of differences at $\mathrm{P} \leq 0.05$. The calculation was performed for completely randomized design with three replications per treatment.

\section{RESULTS}

At high temperature, $P$. rhoeas did not show a varying response to herbicides, although its plants 
tended to be more susceptible to tribenuron methyl than to the other herbicides. Low temperature differentiated the response of poppy plants to herbicides. The greatest biomass reduction was noted for plants sprayed with tribenuron methyl, while the weakest reaction to herbicide stress was found for plants exposed to the mixture of 2.4-D with dicamba, producing only a 52\% biomass reduction (Table 1).

Relative humidity did not affect the reaction of $P$. rhoeas to the herbicides. Plants of $P$. rhoeas were highly susceptible to tribenuron methyl and 2.4-D + florasulam at both 50 and $75 \%$ relative humidity and much less sensitive to 2.4-D + dicamba (Table 1).

Table 1

Biomass reduction of $P$. rhoeas treated with herbicides under various temperature and relative humidity conditions

\begin{tabular}{ccccc}
\hline \multirow{2}{*}{$\begin{array}{c}\text { Environmental } \\
\text { factor }\end{array}$} & \multicolumn{3}{c}{ Fresh weight reduction $(\%)$} \\
\cline { 2 - 5 } & $\begin{array}{c}\text { tribenuron } \\
\text { methyl }\end{array}$ & $\begin{array}{c}2.4-\mathrm{D}+ \\
\text { florasulam }\end{array}$ & $\begin{array}{c}2.4-\mathrm{D}+ \\
\text { dicamba }\end{array}$ \\
\hline \multirow{2}{*}{ Temperature } & $25 / 16^{\circ} \mathrm{C}$ & $94 \mathrm{a}$ & $88 \mathrm{a}$ & $85 \mathrm{a}$ \\
& $8 / 2{ }^{\circ} \mathrm{C}$ & $83 \mathrm{a}$ & $74 \mathrm{~b}$ & $52 \mathrm{c}$ \\
\hline Relative & $75 \%$ & $94 \mathrm{a}$ & $97 \mathrm{a}$ & $76 \mathrm{~b}$ \\
humidity & $50 \%$ & $92 \mathrm{a}$ & $97 \mathrm{a}$ & $69 \mathrm{~b}$ \\
\hline
\end{tabular}

Values marked with the same letter do not differ significantly

Amino acid content in untreated plants of $P$. rhoeas was related to growing conditions. Temperature affected differently the level of amino acids in untreated plants. In all tested samples, the content of valine was the least and it ranged between $2.03 \mathrm{mg} \times$ $\mathrm{kg}^{-1}$ and $15.71 \mathrm{mg} \times \mathrm{kg}^{-1}$. The content of leucine and isoleucine reached similar values and they were a few times higher than that of valine. The sum of amino acids is an appropriate indicator for the evaluation of the impact of individual climatic factors on plants and their response to herbicide stress, therefore this value was took into consideration in the description of the results and in the discussion. The studied weed species differed in total valine, leucine and isoleucine content depending on temperature and relative humidity. A higher amino acid content was found both in the case of plants growing at $8 / 2{ }^{\circ} \mathrm{C}$ compared to those growing at $25 / 16^{\circ} \mathrm{C}$ and in the case of plants growing under $50 \%$ relative humidity conditions compared to $75 \%$. Total amino acid content was more influenced by relative humidity than by temperature (Table $2 \mathrm{a}, 2 \mathrm{~b}$ ).

Tribenuron methyl significantly decreased valine, leucine and isoleucine content in plants of $P$. rhoeas at high and low temperature. A little weaker activity was found for the mixture of 2.4-D with florasulam, irrespective of temperature. An insignificant decrease in amino acid content was observed in plants treated with the mixture of 2.4-D with dicamba (Table 2a). Contrary to temperature, in the relative humidity study no significant differences in the reduction of amino acid content were observed after the exposure of plants to tribenuron methyl and 2.4-D + florasulam. The mixture of 2.4-D with dicamba induced amino acid overproduction, especially at low relative humidity (Table $2 b$ ).

Table 2

Amino acid content $\left(\mathrm{mg} \times \mathrm{kg}^{-1}\right)$ in plants of $P$. rhoeas treated with herbicides under various conditions a. temperature

\begin{tabular}{cccccc}
\hline Temperature & Amino acids & untreated & tribenuron methyl & $2.4-\mathrm{D}+$ florasulam & $2.4-\mathrm{D}+$ dicamba \\
\hline \multirow{3}{*}{$25 / 16^{\circ} \mathrm{C}$} & valine & 8.57 & $1.00^{*}$ & 6.72 & 10.84 \\
& leucine & 38.19 & $1.14^{*}$ & $19.93^{*}$ & 42.60 \\
& isoleucine & 40.20 & $1.72^{*}$ & $21.18^{*}$ & $21.18^{*}$ \\
& total & 86.96 & $3.86^{*}$ & $47.83^{*}$ & $67.34^{*}$ \\
\hline \multirow{3}{*}{$8 / 2^{\circ} \mathrm{C}$} & valine & 15.71 & $4.65^{*}$ & $8.98^{*}$ & 12.00 \\
& leucine & 55.55 & $12.00^{*}$ & $24.3^{*}$ & 54.15 \\
& isoleucine & 65.34 & $10.10^{*}$ & $23.2^{*}$ & 47.73 \\
\hline
\end{tabular}

b. relative humidity

\begin{tabular}{cccccc}
\hline Relative humidity & Amino acids & untreated & tribenuron methyl & 2.4-D + florasulam & 2.4-D + dicamba \\
\hline \multirow{3}{*}{$75 \%$} & valine & 2.03 & 0 & 0 & 0 \\
& leucine & 14.32 & 20.83 & 18.16 & $22.02^{*}$ \\
& isoleucine & 15.98 & 21.69 & 20.05 & $24.98^{*}$ \\
& total & 32.33 & 42.52 & 38.21 & $47.00^{*}$ \\
\hline $50 \%$ & valine & 9.93 & $4.29 *$ & 10.22 & $19.48^{*}$ \\
& leucine & 54.60 & 44.72 & 49.17 & $79.54^{*}$ \\
& isoleucine & 51.07 & 46.85 & 60.33 & 55.78 \\
\hline
\end{tabular}

*The total amino acid content followed by an asterisk is significantly different (at 0.05 ) compared to the no-herbicide treatment 
S. media was highly susceptible to herbicides, irrespective of growth conditions. Biomass productivity was strongly limited (more than $90 \%$ ) under both high and low relative humidity. Temperature differentiated the response of plants to the mixture of 2.4-D with dicamba, resulting in a considerably smaller reduction in fresh weight when plants grew at low temperature (Table 3).

Table 3

Biomass reduction of $S$. media treated with herbicides under various temperature and relative humidity conditions

\begin{tabular}{ccccc}
\hline \multirow{2}{*}{$\begin{array}{c}\text { Environmental } \\
\text { factor }\end{array}$} & \multicolumn{3}{c}{ Fresh weight reduction (\%) } \\
\cline { 2 - 5 } & $\begin{array}{c}\text { tribenuron } \\
\text { methyl }\end{array}$ & $\begin{array}{c}2.4-\mathrm{D}+ \\
\text { florasulam }\end{array}$ & $\begin{array}{c}2.4-\mathrm{D}+ \\
\text { dicamba }\end{array}$ \\
\hline \multirow{2}{*}{ Temperature } & $25 / 16^{\circ} \mathrm{C}$ & $99 \mathrm{a}$ & $100 \mathrm{a}$ & $99 \mathrm{a}$ \\
& $8 / 2{ }^{\circ} \mathrm{C}$ & $91 \mathrm{a}$ & $96 \mathrm{a}$ & $75 \mathrm{~b}$ \\
\hline \multirow{2}{*}{ Relative } & $75 \%$ & $99 \mathrm{a}$ & $97 \mathrm{a}$ & $96 \mathrm{~b}$ \\
humidity & $50 \%$ & $97 \mathrm{a}$ & $97 \mathrm{a}$ & $96 \mathrm{~b}$ \\
\hline
\end{tabular}

Values marked with the same letter do not differ significantly

Temperature and relative humidity affected the level of amino acids in untreated plants. In all tested samples, valine reached the highest value and its content ranged $12.74-12.85 \mathrm{mg} \times \mathrm{kg}^{-1}$ for the temperature study and $4.11-5.18 \mathrm{mg} \times \mathrm{kg}^{-1}$ for the relative humidity study. Similarly to $P$. rhoeas, the content of leucine and isoleucine was found to be approximately six times higher than valine content (Table 4a, 4b).

Plants of S. media growing under warm conditions responded to tribenuron methyl by a significant decrease in valine, leucine and isoleucine. When 2.4-D + florasulam were used, the reduction in amino acid content was only slight, especially in the case of valine. In plants treated with 2.4-D + dicamba, the amino acid level was significantly higher compared to untreated plants. Under low temperature conditions, the amino acid content in plants exposed to tribenuron methyl was higher than under high temperature conditions. At low temperature, the mixture of 2.4-D with florasulam and 2.4-D with dicamba did not affect the level of amino acids, while under high temperature conditions they caused a significant decrease in leucine and isoleucine (Table 4a). Greater differences in amino acid content between untreated plants and herbicide-treated plants were found in plants growing at low relative humidity. Similarly to the temperature study, there was a significant reduction in total amino acid content in plants treated with tribenuron methyl and with 2.4-D + florasulam, but an increase in plants sprayed with 2.4-D + dicamba. At high relative humidity, a difference was found only for plants sprayed with the mixture of 2.4-D with dicamba (Table $4 b$ ).

Table 4

Amino acid content $\left(\mathrm{mg} \times \mathrm{kg}^{-1}\right)$ in plants of $S$. media treated with herbicides under various conditions

a. temperature

\begin{tabular}{cccccc}
\hline Temperature & Amino acids & untreated & tribenuron methyl & 2.4-D + florasulam & $2.4-\mathrm{D}+$ dicamba \\
\hline \multirow{3}{*}{$25 / 16^{\circ} \mathrm{C}$} & valine & 12.85 & $3.94^{*}$ & 10.50 & 16.11 \\
& leucine & 41.67 & $2.10^{*}$ & $24.16^{*}$ & $65.43^{*}$ \\
& isoleucine & 42.61 & $3.18^{*}$ & $30.72^{*}$ & $68.05^{*}$ \\
& total & 97.13 & $9.22^{*}$ & $65.38^{*}$ & $149.59^{*}$ \\
\hline \multirow{2}{*}{$8 / 2{ }^{\circ} \mathrm{C}$} & valine & 12.74 & 8.86 & 11.00 & 18.60 \\
& leucine & 72.66 & 4.17 & 42.40 & 85.80 \\
& isoleucine & 68.40 & 5.08 & 44.30 & 86.20 \\
\cline { 2 - 5 } & total & 153.80 & $18.11^{*}$ & $97.70^{*}$ & $190.60^{*}$ \\
\hline
\end{tabular}

b. relative humidity

\begin{tabular}{cccccc}
\hline Relative humidity & Amino acids & untreated & tribenuron methyl & 2.4-D + florasulam & 2.4-D + dicamba \\
\hline \multirow{3}{*}{$75 \%$} & valine & 4.11 & 8.57 & 4.06 & 7.22 \\
& leucine & 15.00 & 12.92 & 12.49 & 26.15 \\
& isoleucine & 16.36 & 15.72 & 15.72 & 31.00 \\
\hline \multirow{2}{*}{$50 \%$} & total & 35.47 & 37.21 & 32.27 & $64,37 *$ \\
& valine & 5.18 & 1.61 & 3.19 & 5.85 \\
& leucine & 28.50 & 14.02 & 22.32 & 39.16 \\
& isoleucine & 22.77 & 12.34 & 20.88 & 43.50 \\
\hline
\end{tabular}

* The total amino acid content followed by an asterisk is significantly different (at 0.05 ) compared to the no-herbicide treatment 


\section{DISCUSSION}

The reduction in biomass and in the content of amino acids studied in field poppy and common chickweed plants was dependent on weed species, herbicide type, and climate conditions. Among the herbicides, the mixture of 2.4-D with dicamba was the most related to environmental conditions, especially to temperature, regardless of weed species. It resulted in significantly smaller biomass reduction when both weed species were kept at low temperature in comparison with high temperature, while the mixture of 2.4-D with florasulam caused differences only when it was used against $P$. rhoeas. This agrees with the results obtained by Coetzer et al. [4] as well as Johnson and Young [16] who reported that particular weed species responded to herbicides applied under variable temperature regimes differently or some of them were not temperature dependent. Moreover, this study showed greater biomass reduction under warm conditions for the mixtures 2.4-D+dicamba and 2.4-D+florasulam. These results are in agreement with the previous reports describing higher herbicide activity under high temperature conditions compared to low temperature $[5,16,17]$. In contrast to temperature, relative humidity did not influence weed response to herbicide stress. Similar results were reported by F a u s e y and Renner [17], but generally this finding is inconsistent with most of the previous papers that have proven a weaker response of weeds to herbicides at low relative humidity $[4,18,19]$. The lack of differences in weed response proved in this research may be due to the small differences between the relative humidity levels tested.

Changes in free amino acid content can be an indicator of plant response to herbicides [13]. The greatest changes in the level of amino acids are observed when weeds are treated with herbicides influencing the biosynthesis of these components. Sulfonylurea herbicides act by inhibiting the acetolactate synthase (ALS) - the key enzyme in the biosynthesis of branched-chain amino acids: valine, leucin and isoleucine [1]. According to their mode of action, the level of amino acids in plants treated with tribenuron methyl was considerably lower compared to untreated weeds, regardless of temperature and at low relative humidity, while at high relative humidity it was similar to the no herbicide treatment. Deficiency of branched-chain amino acids (valine, leucine and isoleucine) as a result of their biosynthesis inhibition in plants treated with ALS inhibitors was described by Shaner and S ing h [20]. Similarly, M a r zew sk a et al. [21] found that weeds sensitive to ALS-inhibitor responded by a significant reduction in fresh weight and amino acid content. Moreover, the higher reduction in amino acid content in plants of $P$. rhoeas at $25 / 16^{\circ} \mathrm{C}$ compared to $8 / 2{ }^{\circ} \mathrm{C}$, which was observed in this study, suggests a stronger response to tribenuron methyl under warm conditions. In the case of S. media, the decrease in amino acid content was similar for both temperature regimes, which may be explained by a weak relationship between temperature and plant response to tribenuron methyl. These findings are in agreement with the previous study that reported a lower level of amino acids in weeds exposed to herbicides under warm compared to cold conditions [22]. An opposite response was observed in weeds sprayed with the mixture of 2.4-D with dicamba. There was an increase regardless of temperature or relative humidity. Being typical auxinic herbicides, this mixture stimulates physiological processes leading to unrestricted plant growth, including tissues, cells and organic compounds like amino acids.

Some data obtained from this study on amino acids were not always reflected in a decrease in fresh weight and therefore they may suggest weak ALS-inhibitor activity when biomass is compared to the amino acid content in untreated plant. The study also found that there was no increase in amino acid content in plants of $P$. rhoeas, which had been expected as a result of the application of the mixture of 2.4-D + dicamba. This incoherence makes it difficult to give an unequivocal conclusion about weed response, because apart from herbicide activity, amino acid content in plant tissues is influenced by numerous factors and therefore it is not always possible to obtain results that may be correlated with biomass productivity.

\section{CONCLUSIONS}

1. Temperature affected biomass reduction of Papaver rhoeas treated with the mixture of 2.4-D with florasulam and 2.4-D with dicamba. Relative humidity did not differentiate the response of plants to the herbicides.

2. Stellaria media was sensitive to tribenuron methyl and the mixture of 2.4-D with florasulam, regardless of temperature and relative humidity. Its sensitivity was significantly reduced when plants were sprayed with the mixture of 2.4-D with dicamba under low temperature conditions.

3. Tribenuron methyl applied to both weed species under various temperature regimes caused significant amino acid deficiency. In most cases, the mixture of 2.4-D + dicamba induced overproduction of amino acids, regardless of climate factors.

4. The reduction in amino acid content in P. rhoeas plants was greater at warm temperature compared to the cold regime due to a stronger response to tribenuron methyl applied under these conditions. 


\section{Acknowledgments}

The research was supported by the project NN 310203937 from the Ministry of Science and Higher Education in Poland.

\section{Authors' contributions}

The following declarations about authors' contributions to the research have been made: design of the experiments: RK, KD; performance of the experiments: RK, JS; analysis of the experimental data: RK; writing of the paper: RK.

\section{REFERENCES}

1. Ray T.B. Site of action of chlorsulfuron. Inhibition of valine and isoleucine biosynthesis in plants. Plant Physiol. 1984; 75(3): 827-831. http://dx.doi.org/10.1104/pp. 75.3 .827

2. Grossman K. Mode of action of auxin herbicides: a new ending to a long, drawn out story. Trends Plant Sci. 2000; 5(12): 506-508. http://dx.doi.org/10.1016/S1360-1385 (00)01791-X

3. Chachalis D., Reddy K.N., Elmore C.D., Ste ele M.L. Herbicide efficacy, leaf structure, and spray dropletcontact angle among Ipomoe $a$ species and smallflower morningglory. Weed Sci.2001;49(5):628-634.http://dx.doi. org/10.1614/0043-1745(2001)049[0628:HELS A$\mathrm{S}] 2.0 . \mathrm{CO} ; 2$

4. Coetzer E., Al-Khatib K., Loughin T.M. Glufosinate efficacy, absorption and translocation in amaranth as affected by relative humidity and temperature. Weed Sci. 2001; 49(1): 8-13. http://dx.doi.org/10.1614/0043-1745 (2001)049[0008:GEAATI]2.0.CO;2

5. Kudsk P., Kristensen J.L. Effect of environmental factors on herbicide performance. Proceedings of The First International Weed Control Congress, 17-21 February 1992, Melbourne, Australia, pp. 173-185.

6. Zhou Q., Liu W., Zhang Y., Liu K.K. Action mechanisms of acetolactate synthase-inhibiting herbicides. Pestic Biochem Physiol. 2007; 89(2): 89-96. http://dx.doi. org/10.1016/j.pestbp.2007.04.004

7. Durán-Serantes B., Gonzáles L., Reigosa M.J. Comparative physiological effects of three allelochemicals and two herbicides on Dactylis glomerata. Acta Physiol Plant. 2002; 24(4): 385-392. http://dx.doi.org/10.1007/ s11738-002-0034-4

8. Fayez K.A., Kristen U. The influence of herbicides on the growth and proline content of primary roots and on the ultrastructure of the root caps. Environ Exp Bot. 1996; 36(1): 71-81. http://dx.doi.org/10.1016/0098-8472 (95)00036-4

9. Huang H., Xiong Z.T. Toxic effects of cadmium, acetochlor and bensulfuron-methyl on nitrogen metabolism and plant growth in rice seedlings. Pestic Biochem Physiol. 2009; 94(2-3): 64-67. http://dx.doi.org/10.1016/j. pestbp.2009.04.003
10. Petersen I.L., Bruun Hansen H.Ch., Ravn H.W., Srrrsen J.Ch., Sřrsen H. Metabolic effects in rapeseed (Brassica napus L.) seedlings after root exposure to glyphosate. Pestic Biochem Physiol. 2007; 89(3): 220-229. http:// dx.doi.org/10.1016/j.pestbp.2007.06.009

11. Sellers B.A., Smeda R.J., Li J. Glutamine synthetase activity and ammonium accumulation is influenced by time of glufosinate application. Pestic Biochem Physiol. 2004; 78(1): 9-20. http://dx.doi.org/10.1016/j.pestbp. 2003.09.006

12. Starratt A.N., Lazarovits G. Increases in free amino acid levels in tomato plants accompanying herbicide-induced disease resistance. Pestic Biochem Physiol. 1996; 54(3): 230-240. http://dx.doi.org/10.1006/pest.1996.0027

13. Shim S.I., Lee B.M., Ryu E.I., Kang B.H. Response of leaf acetolactate synthase from different leaf positions and seedling ages to sulfonylurea herbicide. Pestic Biochem Physiol. 2003; 75(1-2): 39-46. http://dx.doi. org/10.1016/S0048-3575(03)00016-6

14. Bestman H.D., Devine M.D., Vanden Born W.H. Herbicide chlorsulfuron decreases assimilate transport out of treated leaves of Field Pennycress (Thlaspi arvense L.) seedlings. Plant Physiol. 1990; 93(4): 1441-1448. http://dx. doi.org/10.1104/pp.93.4.1441

15. Hjorth M., Mathiassen S.K., Kudsk P., $\mathrm{Ravn} \mathrm{H.W.} \mathrm{Amino} \mathrm{acids} \mathrm{in} \mathrm{loose} \mathrm{silky-bent} \mathrm{(Apera}$ spica-venti (L.) Beauv.) responding to prosulfocarb exposure and the correlation with physiological effects. Pestic Biochem Physiol. 2006; 86(3): 138-145. http://dx.doi.org/ 10.1016/j.pestbp.2006.02.006

16. Johnson B.C., Young B.G. Influence of temperature and relative humidity on the foliar activity of mesotrione. Weed Sci. 2002;50(2):157-161. http://dx.doi.org/ 10.1614/0043-1745(2002)050[0157:IOTARH]2.0.CO;2

17. Fausey J.C., Renner K.A. Environmental effects on CGA-248757 and flumiclorac efficacy/soybean tolerance. Weed Sci. 2001; 49(5): 668-674. http://dx.doi.org/ 10.1614/0043-1745(2001)049[0668:EEOCAF]2.0.CO;2

18. Ramsey R.J.L., Stephenson G.R., Hall J.C. Effect of relative humidity on the uptake, translocation and efficacy of glufosinate ammonium in wild oat (Avena fatua). Pestic. Biochem. Physiol. 2002; 73(1): 1-8. http:// dx.doi.org/10.1016/S0048-3575(02)00017-2

19. Ramsey R.J.L., Stephenson G.R., Hall J.C. Effect of humectants on the uptake and efficacy of glufosinate in wild oat (Avena fatua) plants and isolated cuticles under dry conditions. Weed Sci. 2006; 54(2): 205-211. http://dx.doi.org/10.1614/WS-05-051R.1

20. Shaner D.L., Singh B.K. How does inhibition of amino acids biosynthesis kill plants? In: Singh BK, Flores HE, Shannon JC (eds) Biosynthesis and molecular regulation of amino acids in plants. American Society of Plant Physiologist, Rockville, Md, 1992, pp. 174-183.

21. Marczewska K., Rola H., Sadowski J. Wolne aminokwasy wskaźnikiem odporności chwastów na chlorosulfuron. / Free amino acids as an index of weeds resistance to chlorosulfuron. Prog. Plant Prot. / Post. Ochr. Rośl. 2007; 47(3): 199-205. (in Polish) 
22. Kieloch R., Sadowski J., Domaradzki K. Wpływ tribenuronu metylu oraz mieszaniny $2,4-\mathrm{D}+$ florasulam stosowanych w zróżnicowanych warunkach termicznych na zawartość aminokwasów w wybranych gatunkach chwastów. / The influence of tribenuron methyl and 2,4-D + florasulam applied under various thermal conditions on amino acids content in selected weed species. Prog. Plant Prot. / Post. Ochr. Rośl. 2011; 51(2): 976-981. (in Polish)

\section{Zawartość aminokwasów i produktywność biomasy wybranych gatunków chwastów jako wskaźnik ich reakcji na stres herbicydowy}

\section{Streszczenie}

W pracy określono redukcję biomasy oraz zawartość aminokwasów w roślinach Papaver rhoeas L. i Stellaria media L. w celu oceny reakcji tych gatunków na stres herbicydowy w zróżnicowanych warunkach temperatury $\left(25 / 16 \mathrm{i} 8 / 2{ }^{\circ} \mathrm{C}\right)$ i względnej wilgotności powietrza (50 i 75\%). Rośliny potraktowano tribenuronem metylu $\left(15 \mathrm{~g} \times \mathrm{ha}^{-1}\right)$, mieszaniną 2,4-D $\mathrm{z}$ florasulamem $\left(180+3,75 \mathrm{~g} \times \mathrm{ha}^{-1}\right)$ i mieszaniną 2,4-D z dikambą $\left(1252,5+97,5 \mathrm{~g} \times\right.$ ha $\left.^{-1}\right)$. Określono świeżą masę chwastów i zawartość wolnych aminokwasów o łańcuchach rozgałęzionych (waliny, leucyny i izoleucyny) w ich tkankach. Herbicydem najsilniej ograniczającym produktywność biomasy był tribenuron metylu, niezależnie od gatunku chwastu oraz czynnika klimatycznego. S. media była bardziej wrażliwa na herbicydy niż $P$. rhoeas. Reakcja chwastów była zależna od temperatury, natomiast nie była zależna od wilgotności powietrza. Tribenuron metylu zastosowany w zróżnicowanych warunkach temperaturowych spowodował znaczący ubytek zawartości aminokwasów w obu gatunkach chwastów. Redukcja zawartości aminokwasów w roślinach $P$. rhoeas była większa $\mathrm{w}$ warunkach ciepłych $\mathrm{w}$ porównaniu z chłodnymi, z powodu silniejszej reakcji na tribenuron metylu aplikowany w tych warunkach. W większości przypadków, mieszanina 2,4-D + dikamba wywoływała zwiększoną produkcję aminokwasów.

Handling Editor: Elżbieta Weryszko-Chmielewska

This is an Open Access digital version of the article distributed under the terms of the Creative Commons Attribution 3.0 License (creativecommons.org/licenses/by/3.0/), which permits redistribution, commercial and non-commercial, provided that the article is properly cited. 